\title{
UNDERSTANDING GANG-RECRUITMENT THROUGH SELECTIVE INCENTIVES: THE CASE OF HONDURAS.
}

Entendiendo el reclutamiento de pandillas a traves de incentivos

selectivos: El caso de Honduras.

Victoria E. Carmona Bozo

\begin{abstract}
Since their origins in the 1960s, criminal organizations in Latin America have been responsible for brutal acts of violence in the region. However, very little is known about the specific mechanisms involved in their recruitment tactics. Empirical evidence demonstrates that the use of selective incentives is widespread among gangs to compel membership.
\end{abstract}

This essay considers both the shape and character of Honduran gang members and attempts to highlight the complex phenomenon of gang recruitment. I will advance a twofold approach of the selective incentives theory of rebel recruitment to identify the significant mechanisms at play in the recruitment of citizens to join violent gangs. Understanding the processes of recruitment involved in the Honduran case will potentially contribute to better plan and execute interventions to reduce gang violence in the Northern Triangle countries (Honduras, Guatemala and El Salvador) and Latin America at large.

Key words: Honduras, Gang recruitment, gang violence, maras.

\section{RESUMEN}

Desde sus orígenes, en la década de 1960, las organizaciones criminales en América Latina han sido responsables de actos brutales de violencia en la región. Sin embargo, se sabe muy poco acerca de los mecanismos específicos involucrados en sus tácticas de reclutamiento. La evidencia empírica demuestra que el uso de incentivos selectivos está muy extendido entre las pandillas para obligar a los miembros.

1 Politóloga y Psicóloga de la Universidad de Nueva York. Magister (C) en estudios de Paz y Conflicto de la Uppsala University, Department of Peace and Conflict Studies. ORCID ID: https://orcid.org/0000-0001-7705-7775 E-mail: vickycarmona1@gmail.com 
Este ensayo considera la forma y el carácter de los pandilleros hondureños e intenta resaltar el complejo fenómeno del reclutamiento de pandillas. Presentaré un doble enfoque de la teoría de incentivos selectivos del reclutamiento de rebeldes para identificar los mecanismos significativos en juego en el reclutamiento de ciudadanos para unirse a pandillas violentas. Comprender los procesos de reclutamiento involucrados en el caso hondureño contribuirá, potencialmente, a planificar y ejecutar mejor las intervenciones para reducir la violencia de pandillas en los países del Triángulo del Norte (Honduras, Guatemala y El Salvador) y América Latina en general.

Palabras clave: Honduras, reclutamiento de pandillas, violencia de pandillas, maras.

\section{INTRODUCTION}

Previous theory has pointed to the relevance of selective incentives to explain the logic behind Mancur Olson's (1965) collective action problem. A study of the phenomenon of gang recruitment may provide further insight into why, at the individual level, people choose to participate in collective action. Individuals who form the support bases of both rebel groups and criminal gangs can be seen as rational actors basing their decisions to participate in cost-benefit analyses. Similarly to joining an insurgency, participation in the gangs is costly and dangerous. In most gang-ridden areas, insecurity is staggeringly high and inter-gang violence is common. Just as a rebel in an armed conflict, the ultimate private cost facing a gang member is death. Furthermore, criminal gangs are rebellious against governments. In this sense, they compete against governments for control of markets in an economy and territory, for example. Since their origins in the 1960s, criminal organizations in Latin America have been responsible for brutal acts of violence in the region. However, very little is known about the specific mechanisms involved in their recruitment tactics. While previous literature on the subject of gang recruitment is minimal, empirical evidence demonstrates that the use of selective incentives is widespread among gangs to compel membership. For all of the aforementioned reasons, I argue the selective incentives theoretical framework should be applied to the phenomenon of gang recruitment.

I decided to focus the analysis of this case study on the years of 2000, when gang-related insecurity first became visible (International Crisis Group 2017), until today, in Honduras, a country which has experienced globally high murder rates during this time period. In 2012, 2014 and 2016, Honduras topped the list of most violent countries in the world (Insight Crime and Asociación para una sociedad más justa, 2016). This essay considers both the shape and character of Honduran gang members and attempts to highlight the complex phenomenon of gang recruitment. I will advance a twofold approach of the selective incentives theory of rebel recruitment to identify the significant mechanisms at play in the recruitment of citizens to join violent gangs. Understanding the processes of recruitment involved in the Honduran case will potentially contribute to better plan and execute interventions to reduce gang violence in the Northern Triangle countries (Honduras, Guatemala and El Salvador) and Latin America at large. 


\section{Theories}

This paper focuses on the selective incentives solution to Olson's (1965) collective action problem as applied to the recruitment process by criminal organizations. I aim to compare the selective material incentives versus selective social incentives to understand the phenomenon of gang recruitment in a high-risk environment. When Mancur Olson (1965) first introduced the concept of "selective incentives", it was a controversial and unorthodox proposition. Previous literature focused on micro-perspectives, such as grievances, or macro-perspectives, such as capitalism or other structural (social, economic, or institutional) changes, to prompt a revolution (Lichbach 1994). Building on previous arguments, Olson (1965) introduced the problem of collective action and argued that grievances or market changes were not enough to make individuals revolutionary. The concept of selective incentives was introduced and focused the importance on the individual rather than the group goal. Embedded in a rational-actor theory framework, this concept was later employed by many theorists to solve several forms of social phenomena, such as peasant struggles (Popkin, 1979), to give one example, or the paradox of public choice (Buchanan and Tullock 1962), among numerous others. However, the selective incentives approach is not without complications. It can lead to the "free-rider" problem (Olson 1965) and is relative to the dangers of nonparticipation (Kalyvas and Kocher, 2007). According to the logic of collective action (Olson 1965), free-riding can be brought about by no excludability: if the collective goal or public good can be provided to all of the members, then rational individuals have an incentive to free-ride -by letting others assume the costs of participation. Additionally, if the public good is non-rivalrous, meaning that consumption by one person does not prevent consumption by another, individuals also have an incentive to free ride -or let others pay for the public good. In Olson's words: “Only a separate and selective incentive will stimulate a rational individual in a latent group to act in a group-oriented way... The incentive must be 'selective' so that those who do not ... contribute to the attainment of the group's interest, can be treated differently from those who do" (Olson 1965: 51).

The second caveat to the idea of selective incentives introduced above, refers to Kalyvas and Kocher's (2007) “dangers of nonparticipation." In the context of civil wars, the authors argue that the risks of participating in insurgent collective action are lower than the costs of nonparticipation or even free-riding. As such, this theory questions the centrality of selective incentives as a motivating factor behind individuals' decisions to join a rebellion. For the purposes of this paper, I do not examine the dangers of nonparticipation. Mostly, because empirical evidence does not seem to suggest that nonparticipation is riskier than participation in criminal gangs -and intra-gang violence is high (International Crisis Group Report 2015). I focus on the idea of selective incentives (economic vs. social incentives) because it shows a more insightful and complex interaction of motivating factors behind the dynamics of recruitment. 


\subsection{Theory I (Economic Incentives Theory)}

According to the selective material incentives theory, individual decisions about participation are based on satisfying material self-interest. Humphreys and Weinstein (2008) created an original dataset to test three competing theories of participation in armed conflict: grievances, selective incentives and community pressures. Their innovative empirical analysis focused on the civil war in Sierra Leone (1991-2002); while the authors concluded that the interaction of these three theories predict participation in rebel movements the best, they found that material incentives make participation more likely. Their results show that individuals who were offered diamonds or money were six times more likely to participate in the Revolutionary United Front (RUF). Lichbach (1994), also argued that peasants are rational actors, making decisions about collective action based on their interests and choices, and that selective incentives affect the strategies and tactics of various actors. Lichbach's (1994) inquiry into peasant struggles showed that income levels affect the efficacy of selective incentives. Middle and poorer peasants demand material selective incentives in exchange for participation and their availability determines whether poorer peasants choose to cooperate or stand on the sidelines. In other words, low-income opens windows of opportunity for rebel groups with the capacity to offer material benefits. Others have argued that low-income per capita lowers the opportunity costs for people joining a rebellion, making participation more feasible (Taylor, 1988). The gangs in Honduras offer several economic benefits that are contingent on participation, and, thus, can be understood as selective material incentives. First hypothesis: If material incentives are present and contingent on participation, we should expect individuals to join a gang.

\subsection{Theory II (Social Incentives Theory)}

Several authors have also found a link between the use of social incentives and the recruitment process in conflict scenarios. Wood (2003) argues that honor, reputation, and agency were effective reasons for participating in the insurgent mobilization in El Salvador during the 1970s. Michael Taylor (1988; in Humphreys and Weinstein 2008) relied on the activation of common collective identities or tight social networks for participation in rebellion. For Taylor, "a strong community is defined by (1) a membership with shared values and beliefs; (2) relations between members which are direct and many sided; and (3) practices within the community of generalized reciprocity (Taylor 1988 in Humphreys and Weinstein 2008). Following the author's logic, the existence of social cohesion at the community-level facilitates collective action through norms of reciprocity. Weinstein (2005) argues that social incentives may substitute economic rewards for cooperation in situations where the rebels lack economic endowments and where interaction among the members is high and reputation matters. Humphreys and Weinstein (2008) found that among those who elected to join voluntarily the RUF in Sierra Leone, social ties were a determining factor. In the same study, the authors found that community cohesion (whether members of the community were active in the movement and the community was characterized by strong social structures) 
predicted CDF recruitment across all specifications. Keser and van Winden (2000) found that individuals can experience at least a minimal amount of satisfaction from cooperation because they feel like they are part of the group. Another approach posits social approval at the center of the social dilemma. "When individuals receive either high or low levels of social approval, it has a very positive, significant impact on cooperative behavior" (Cheshire 2007). Second hypothesis: If offering of social endowments by the gang leadership is present, we should expect participation of citizens in the criminal gangs.

\section{Methodology}

The dependent variable in this study is gang recruitment. There are two main criminal gangs in Honduras: Barrio 18 and MS13. I define recruitment as participation in any of these two gangs. Engagement in violence is not necessary, but membership is sufficient a requirement for inclusion.

The independent variable in the first hypothesis is the presence of economic incentives that are contingent upon participation. To test this hypothesis, I will examine the recruitment strategies of Barrio 18 and MS13 and determine whether the leaders of these organizations offer private economic benefits in exchange for affiliation. If any material selective incentives are offered, such as jobs, money, or food, we should expect individuals to join the gang. Because the efficacy of material selective incentives has been connected to an individual's economic condition (Lichbach 1994), it is also important to evaluate the income-level of individuals who join gangs and whether they have alternative means of economic survival, such as wages. Thus, I will also look at poverty and unemployment levels among gang members. Following Lichbach's (1994) logic, empirical observation should reveal the following patterns: people who are poorer and/or lack alternative earnings will demand or accept material benefits in exchange for affiliation. In this case, the employment of selective economic incentives motivates individuals' desire to participate by covering their basic survival needs, such as food, household, or income. Moreover, rational individuals will participate to maximize their earnings and achieve a livelihood.

The independent variable in the second hypothesis is the presence of social selective incentives. I define these incentives as private social benefits derived from recruitment, which are contingent upon participation. Social endowments may be based on shared norms, shared identities, trust and social capital within existing networks. In order to test this hypothesis, I will determine whether the two main criminal organizations in Honduras offer social selective incentives in exchange for recruitment. I will look at the norms and values of criminal gangs to determine whether there is a clear collective identity among their members. The causal mechanism at play would be that individuals join a gang to earn a sense of identity or wellbeing derived from the collective identity of the group. Building on Taylor's (1988) argument, I will evaluate the presence of strong communal ties that would facilitate cooperation. Specifically, I will measure if individuals were invited to join the gang by a neighbor, friend, or relative. In socially cohesive communities, individuals will be 
motivated to join a gang if other community members have also joined the gang, through norms of reciprocity. Finally, a proxy indicator for the existence of social selective incentives will be whether individuals who join criminal gangs come from broken or dysfunctional families. In this case, individuals will be motivated to join because gangs provide a support network that prospective members are otherwise lacking.

This case study is an empirical observation of the recruitment tactics of the two main criminal gangs in Honduras since the year 2000, when gang-related insecurity became visible (International Crisis Group 2017), until today. In terms of sources, I will look at an International Crisis Group (ICG) Report, based on dozens of interviews with officials and experts in Honduras. I will also look at an Insights Crime Report called "Gangs in Honduras", produced for review by the United States Agency for International Development (USAID). I will draw information from a WorldBank original survey-report looking at gang membership and development from 2009 until 2012. Finally, I will look at relevant articles in several academic magazines. All of these sources are reliable and have been widely cited by previous authors writing on this topic.

\section{Case study + Analysis}

\section{Introduction of The Case Study}

There are two main criminal bands or maras in Honduras, one is MS13 and the other Barrio 18 (more commonly known as the "dieciocho"), among other smaller criminal bands. For the purposes of this study, I do not differentiate between the recruitment tactics of these two gangs. The main reason is that both of these organizations exhibit similar behaviors. They are nominally hierarchical in structure and rely on revenue from criminal activities such as extortion, kidnapping, and the drug trade. Second, there is no evidence in the literature suggesting that they exhibit differences in their recruitment profiles. According to an International Crisis Group Report (2017), "many of the murders in El Salvador and Honduras... can be ascribed to confrontations with the police, rivalries, score-settling or intimidation carried out by the two outstanding mara organisations: the Mara Salvatrucha (MS-13); and the Barrio 18". The report goes on to explain how mara members primarily target members of competing violent organizations. Most members join gangs between the ages of 11 and 20 years old and the populations most at risk of joining are "vulnerable children and young people, orphans and those without access to public services" (UNICEF 2012). Like the latter, existing narratives of why citizens join violent gangs identify risk factors at both the social and economic ends of the spectrum, which is why the main question at the center of this study becomes more relevant.

\subsection{Analysis of Theory I}

The gangs in Honduras are self-sufficient, organized, business-oriented structures, all of which point to a factor of economic attractiveness inherent in the gang's criminal lifestyle. There is 
widespread evidence of the gangs offering immediate employment opportunities to other criminals with special skills, particularly in the financial and military fields (Berg and Carranza. 2015). MS 13, for instance, is divided into neighborhood structures called "clicas", which are hierarchical structures grouped into cells that respond to the national leadership in each country; each clica relies on criminal activities to obtain their economic revenue and are responsible for payments to the central leadership (Douglas and Babineau 2018: 59). An article from the academic magazine PRISM shows there is a clear presence of economic incentives available by joining the gang:

According to a policeman who has been offered work by MS 13 and has several friends who have accepted the offer, MS 13 pays roughly 2.5 times what the policemen were making inside the police force... The widespread availability of unemployed policemen has not only benefitted MS 13; many dismissed policemen have branched out into their own freelance criminal activity (kidnapping, extortion), or joined some of the rapidly-growing groups that offer specialized criminal services, like the Olanchos, who specialize in murder for hire, or Los Ponce and Los Tercereños, who now compete with MS 13 for control of drug transport routes (Douglas and Babineau 2018: 64)

Another argument in support of the economic incentives theory might be that the criminal gangs are most present in the poor urban enclaves. Since their origins, gangs took root in marginal urban communities characterized by negligible public services, lack of primary schools, and limited economic opportunities. Some cities in these contexts have struggled to keep up with changing trade flows, urban migration, and the growth of illicit economies, associated with significant increase in the membership of gangs (Berg and Carranza, 2015). Furthermore, the geographic distribution of gangs in Honduras shows that gangs are concentrated in poor areas with generalized high-levels of youth unemployment (Insight Crime and Asociaición para una sociedad más justa. 2016). This analysis outlays a clear causal mechanism relevant in the recruitment of gang members in Honduras. Namely, that people, especially the youth, join gangs to cover basic subsistence needs. The criminal livelihood provides for the necessary salary for members to survive and take care of their families. As evidenced, this causal mechanism is boosted in neighborhoods where the opportunity costs for joining a gang are lower. For example, in territories where there are limited economic opportunities (measured by high measures of youth unemployment), the pursue of a criminal livelihood becomes more attractive. Given all of these considerations, there is support for the first hypothesis.

\subsection{Analysis of Theory II}

According to Tomas Ayuso, author of an article in the National Geographic magazine: "Gang recruits are groomed from a young age... They're first asked to run errands then given small tasks until they reach the point of being inducted into the gang through a grueling rite of passage" (Ayuso 2018). This statement points to the psychological factors involved in the recruitment of members by the violent gangs. In the same article, Ayuso writes that when visiting a gang turf in a poor district of the capital city, San Pedro Sula, he expected to encounter a district dominated by a ruthless group of criminals. 
Instead, he claims to have found "locals living in a tenuous state of calm alongside gang enforcers who were their neighbors, sons and cousins." Most of the youth quoted in the article were persuaded to join the gangs by their childhood friends or family members. In many instances, the gang even substituted a family structure that the youngsters lacked -for example, because they had been orphaned as children or abandoned by their parents. These personal testimonies support the social incentives theory of recruitment.

According to the ICG report, gangs serve a two-faceted purpose for members: as a social support network and as apparatuses of coercion and predation. "Emotional satisfaction - gaining status, respect and a strong sense of collective identity - has always been integral to the attractions of gang life, and has played a far more important role in the rise and resilience of gangs than the illicit accumulation of wealth. Gangs in effect provide a psychological crutch and a social life, especially for bored young men from broken families." In this sense, gangs substitute a family for their members and provide friends from fellow "mareros", with whom members spend most of their time. Also according to the ICG report, maras or gang members commit most of their crimes in groups, which adds on to the sense of belonging and cohesive solidarity among these groups. In one specific case, a female member joined the MS13 band at the age of eleven. When asked why by the reporter, she said that because her mother "mistreated her too much" (International Crisis Group 2015). She also said that gangs had always surrounded her life and neighbors her age were members as well. This story supports the social incentives theory because the gang offered this girl a niche of solidarity and security with which to replace her home. It is also possible to observe that participation became more attractive because of reciprocity with friends and neighbors. This article also illustrates the existence of a common vocabulary among gang members. Members of the group use a distinctive language, especially when referring to each other, such as "homeboys" and "homegirls", which reveals a strong sense of shared identity. There are also implicit norms of behavior, such as the willingness to endure forced sexual relations with gang leaders as a prelude to teenage girls' recruitment (International Crisis Group 2015), which signals extremely high levels of social cohesion among these groups. This analysis finds ample support for the second hypothesis.

\subsection{Comparisons of Theories}

The evidence demonstrates that both the material selective incentives and social selective incentives theories help to establish the phenomenon of gang recruitment. However, more evidence seems to support the explanatory power of the social selective incentives hypothesis. While the economic selective incentives theory shows that individuals who join gangs have a clear and reasonable expectation to receive material benefits in exchange for participation; it does a meager job explaining why individuals join a specific gang as opposed to viable alternative groups, including other gangs or higher level criminal organizations such as drug trafficking cartels. On 
the other hand, the social selective incentives theory was referenced by more empirical studies and personal testimonies. Additionally, the evidence showed support for the causal mechanisms of this theory more clearly. However, it was difficult to observe, based on the available evidence, how the social selective incentives hypothesis could account for the empirical patterns of recruitment in poverty-stricken areas. It has been established in the literature that the theory of selective incentives alone does not substitute for more orthodox explanations about recruitment, for example, welfare measures or state responses to the markets (Lichbach 1994); rather, it is the interaction between seemingly competing theoretical models what better captures this relationship (Humphreys and Weinstein 2008). Parting from the analysis above, it is possible to construct a bathtub model of gang recruitment to illustrate the interactive effects of macro and micro-level theories about recruitment. For the first hypothesis, structural or institutional factors (for instance, poverty) may lead to frustrations and grievances at the individual level, which, in turn, may motivate individuals to accept or demand selective economic incentives, leading to recruitment. For the second hypothesis, general macro-factors including cultural norms, lack of education, or negative psychological environments can be seen as dynamic systems exerting forces that promote unique challenges at the individual level. In one example, negative psychological environments (in schools or communities), at a particular developmental state, may lead the individual to develop inadequate social or intellectual competencies, facilitating the acceptance or demand of social selective incentives in exchange for participation, which would lead to recruitment.

\subsection{Limitations and Alternatives}

One limitation is that determinants of the efficacy of economic selective incentives (namely, poverty and unemployment, which may indicate a relatively high marginal return to benefits) are consistent with competing explanations for recruitment. Poverty or unemployment may be proxies for lack of education or inadequate psychological environments (Bozo de Carmona 2005), which would provide support for the second hypothesis in this study. However, further numerical testing would allow us to identify the validity of the first hypothesis distinctively. By controlling for poverty and unemployment, one can measure the efficacy of economic incentives alone in predicting gang recruitment. Nevertheless, as I argue in this paper, the interaction of these factors is what has been found to hold greater explanatory power. At the same time, it is worth noting that the indicators in this study which emphasize the individual frustrations that I identified as driving recruitment may instead proxy for features such as a lack of agency or greater vulnerability to manipulation by the gang leadership -because of the average young age of members. Another limitation is that this case study assumes that the processes behind gang recruitment are static in nature. While there is no evidence suggesting that the recruitment tactics for either MS13 or Barrio 18 have changed since the early $2000 \mathrm{~s}$, it has been recognized in the literature that the determinants of mobilization vary over time (Humphreys and Weinstein 2008). Furthermore, this empirical case study reaches conclusions based on a single case. The benefits of this setting is that it shows psychological and 
motivational factors which cannot be assessed through larger data studies. However, further theoretical work should be directed at analyzing if the significant relationships found in this case study translate over multiple cases and across different contexts.

\section{Conclusions}

This analysis compared the explanatory power of two types of selective incentives, following the logic behind Olson's (1965) collective action problem, to predict criminal gang recruitment. First, selective economic incentives were considered and defined as any material benefit that was offered in exchange for participation, including jobs, money, or food. The first hypothesis states that we should expect individuals to join a criminal gang if selective economic incentives are made available by the gang leadership. Second, selective social incentives were studied and defined as private social benefits derived from recruitment; they may be based on shared norms, shared identities, trust and social capital within existing networks. The second hypothesis states that if social selective incentives are present, we should expect individuals to join a criminal gang. An empirical analysis of the two main criminal gangs in Honduras, since the year 2000 until now, showed that there is support for both of these hypotheses. However, more evidence lends support to the social selective incentives theory. The interaction of the two hypotheses predicts recruitment the most. Finally, this analysis revealed the value of examining existing theories of rebel recruitment in criminal gang recruitment scenarios. Beyond understanding the specific phenomenon of gang recruitment, a study of selective incentives under this framework can aid us in revealing fundamental truths about individual and group participation in collective action.

\section{BIBLIOGRAPHIC REFERENCES}

Ayuso, Tomás. 2018. "In Gang-Ridden Honduras, Growing Old is a Privilege, Not a Right." National Geographic Magazine, February 7, 2018. Retrieved from https://www.nationalgeographic. com/photography/proof/2018/february/honduras-gang-violence-migration-corruption-boys/

Berg, Louis-Alexandre and Carranza, Marlon. 2015. Crime, Violence, and Community-Based Prevention in Honduras. 97642, Research Report. Justice, Security and Development series. Washington: International Bank for Reconstruction and Development/The World Bank. Retrieved from http://documents.worldbank.org/curated/en/930411467996981525/ pdf/97642-REPLACEMENT-FILE-Honduras-Research-Report-Online.pdf

Bozo de Carmona; A. (2005) Globalización y democracia: Referencia a los Derechos Humanos y a la ciudadanía. Filosofia dei Diritti Umani. An VII-Fasc. 19-20. Genn-Ago 2005

Bozo de Carmona, A. (2014). La Democracia igualitarista no es mi apuesta. En Universidad Austral de Chile, Universidad de Carabobo, Universidad de Los Andes, Universidad de Oriente Editores, Miradas Múltiples, Homenaje a Rigoberto Lanz (pp. 267-274) Caracas, Venezuela: Bid\&Co Ed. 
Bozo de Carmona, A. (2012) La universidad debe ser un espacio emblemático de producción de conocimientos. En Ministerio del Poder Popular para la Educación Universitaria y Centro Internacional Miranda Editores Colección por la Transformación universitaria (pp. 91-99). Caracas, Venezuela: MPPEU.

Buchanan, J. and Tullock G. 1962. The calculus of consent. Michigan, USA: University of Michigan Press Cheshire, Coye. 2007. "Selective Incentives and Generalized Information Exchange." Social Psychological Quarterly 70, no. 1: 82-100

Douglas Farah and Babineau Kathryn. 2018. "The Evolution of MS 13 in El Salvador and Honduras.” PRISM 7. July 5, 2018. Retrieved from https://cco.ndu.edu/Portals/96/Documents/ prism/prism_7-1/5-Farah.pdf?ver=2017-09-14-133607-060

Humphreys, Macarthan and Jeremy M. Weinstein. 2008. "Who Fights? The Determinants of Participation in Civil War.” American Journal of Political Science 52, no. 2 (April): 436-455.

Insight Crime and Asociación para una sociedad más justa. 2016. Gangs in Honduras. Honduras: United States Agency for International Development. Retrieved from https:/www.insightcrime.org/ images/PDFs/2015/HondurasGangs.pdf

International Crisis Group. 2017. Mafia of the Poor: Gang Violence and Extortion in Central America. Brussels: International Crisis Group. Retrieved from https://www.crisisgroup.org/latin-america-caribbean/central-america/62-mafia-poor-gang-violence-and-extortion-central-america

Kalyvas, Stathis N., and Matthew Adam Kocher. (2007). "How Free is Free Riding in Civil Wars? Violence, Insurgency, and the Collective Action Problem." World Politics 59, no. 2 (January): $177-216$.

Keser, C. and F. van Winden. 2000. "Conditional Cooperation and Voluntary Contributions to Public Goods." Scandinavian Journal of Economics 102, 1:23-39

Lichbach, Mark I. 1994. "What Makes Rational Peasants Revolutionary? Dilemma, Paradox, and Irony in Peasant Collective Action.” World Politics, 46, no. 3 (April): 383-418.

Olson, Mancur. 1965. The Logic of Collective Action. Cambridge: Harvard University Press.

Popkin, Samuel. 1979. The rational peasant. The political economy of rural society in Vietnam. California, USA: University of California Press. 
Taylor, C. 1988. Youth gangs organize quest for power, Money. In School Safety: National School Safety Center News Journal: 26-27

UNICEF. 2012. Status of Gangs in Honduras. Honduras: UNICEF. Retrieved from https://www. unicef.org/protection/honduras_65204.html

Weinstein, Jeremy M. 2005. "Resources and the Information Problem in Rebel Recruitment." The Journal of Conflict Resolution, 49, no. 4 (August): 598:624.

Wood, Elisabeth J. 2003. Insurgent Collective Action and Civil War in El Salvador. Cambridge: Cambridge University Press. 